Recommended Specifications for Some Metric Measuring Instruments in the Canadian Forestry Sector - December 1976 - Edited by Dr. Y. Richard.

From: Metric Commission Canada, 301 Elgin Street, OTTAWA, Ontario. K1A $0 \mathrm{H} 5$.

Metric Conversion Plan for Sector 8.10 - Forestry. Summary of Metric Conversion Plan for Sector 8.10 - Forestry.

Metric Conversion Plan for Sector 8.20 - Wood.
Summary of Metric Conversion Plan for Sector 8.20 - Wood.

Other publications not pertaining directly to forestry also are available from Metric Commission Canada.

From: Canadian Standards Association, 178 Rexdale Blvd., REXDALE, Ontario. M9W 1 R3.

C.S.A. Standard 0302.1 M77 - Scaling Roundwood — to be published in late 1977 .

\title{
Across the Manager's Desk
}

There are about 4000 Foresters in Canada, some 3600 of whom are currently practicing in the many and varied fields of forestry.

There will be a $12 \%$ increase in the spring of 1978 when the six Forestry Schools graduate 470 new Foresters, about 420 of which will be looking for jobs in Canadian forestry. In the years thereafter, there will be a further $10 \%$ increase annually from Canadian Forestry Schools and no doubt a few foreign Foresters immigrating.

There will be a sizeable group retiring in the next five to ten years. These will be chiefly from the post-war, ex-service, graduating classes of 1949 and 1950. And to a lesser extent from the graduating classes of 1943 to 1948 . It is a well known fact now-a-days that many retiring foresters enter the consulting field so only about half of these will actually retire from the "practice of forestry".

I estimate, then, that the number of "practicing foresters", or at least the ones "available to practice" will increase by $80 \%$ to a maximum of 6500 by the summer of 1982 .

\section{Where are They?}

Occasionally, people make guesses and periodically I am asked how many Foresters there are in Canada. To trace every living graduate of Canadian Forestry Schools and add a tally of all Foresters working in Canada who are graduates of non-Canadian Schools, including BScF's, BScFE's, MF's and PhD's, would be a herculean, if not impossible task.

However, estimates are easier to come by and can, to my mind, be quite accurate if you ask the right people. Therefore I made a few telephone calls and came up with Table 1. Columns 1,2 and 3 are accurate to August 1977 and column 4 is a list of estimates by knowledgeable people across the country. I subtracted 87 for known and estimated retired's to produce the 3600 "practicing" Foresters and added 400 to represent those who left the profession to teach, enter business or work in some other field. Ergo, the 4000 Foresters in Canada.

\section{The Forestry Schools}

Forestry students, potential Forestry students and Foresters looking for work, visit me or contact me on a fairly regular basis. I found I needed more information on Forestry graduates so sent a questionnaire to the Forestry Schools. Their estimated number of graduates in the next five years is shown in Table 2.

Those "remaining in Canadian Forestry" in Table 2 is derived by subtracting $10 \%$ which is the portion of graduates who either leave the country or leave Forestry as a career (an average of the estimates from the schools, Table 3).

The Accumulated Total Practicing Foresters is self-explanatory until you compare the last figure to the estimate of 6500 above by the summer of 1982. The quoted loss of 405 will be due to deaths, retirements and migration to other professions and/or careers.

Table 3 provides two other interesting sets of figures, those going into post-graduate work and those leaving the province in which they took their training. It appears that Ontario will produce more Foresters who will progress to post-graduate work. Of course, the post-grads will enter the job-hunting field in one to three years after graduation. It also appears that Toronto will produce the greatest number going into post-graduate work in nonforestry fields.

Column 3, Table 3, merely shows that Foresters go where the jobs are. Alberta and New Brunswick export the greatest number but it is believed that a goodly number of their students originate in other provinces also.

Unfortunately Laval did not provide figures for Table 3 but it is felt they would be close to average with most of their graduates staying in the province. 
Table 1.

\begin{tabular}{|c|c|c|c|c|c|}
\hline & 1 & 2 & 3 & 4 & 5 \\
\hline 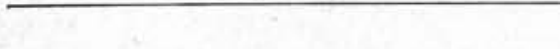 & & CIF & Provincial & Estimated & $\%$ \\
\hline Province & $\begin{array}{c}\text { CIF } \\
\text { Members }\end{array}$ & $\begin{array}{c}\text { Active } \\
\text { Members }\end{array}$ & $\begin{array}{c}\text { Professional } \\
\text { Forester } \\
\text { Members }\end{array}$ & $\begin{array}{l}\text { Number } \\
\text { of } \\
\text { Foresters }\end{array}$ & $\begin{array}{c}\text { each } \\
\text { Province }\end{array}$ \\
\hline 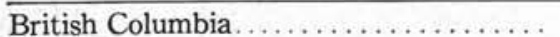 & 620 & 543 & 905 & 980 & 27 \\
\hline Alberta $\ldots \ldots \ldots \ldots \ldots \ldots \ldots$ & 208 & 151 & - & 250 & 7 \\
\hline 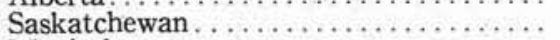 & 54 & 47 & 一 & 65 & 2 \\
\hline 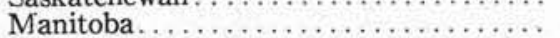 & 27 & 24 & - & 50 & $\overrightarrow{1}$ \\
\hline Ontario $\ldots \ldots \ldots \ldots \ldots \ldots \ldots$ & 698 & 547 & 661 & 900 & 24 \\
\hline Quebec $\therefore \ldots \ldots \ldots \ldots \ldots \ldots \ldots$ & 133 & 111 & 930 & 940 & 25 \\
\hline New Brunswick $\ldots \ldots \ldots \ldots \ldots \ldots \ldots$ & 178 & 134 & 235 & 300 & 8 \\
\hline Prince Edward Island. . . . . . . . . . . . . & 2 & 2 & - & 2 & $<1$ \\
\hline 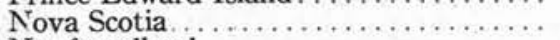 & 76 & $6 \overline{5}$ & - & $12 \overline{5}$ & 3 \\
\hline Newfoundland..$\ldots \ldots \ldots \ldots \ldots \ldots \ldots$ & 50 & 44 & - & 50 & 1 \\
\hline Yukon $\ldots \ldots \ldots \ldots \ldots \ldots \ldots \ldots \ldots$ & 5 & 5 & 一 & 25 & \\
\hline \multirow[t]{2}{*}{ N. W. Territories. . . . . . . . . . . } & 6 & 6 & - & ( & \\
\hline & 2057 & 1679 & 2731 & 3687 & 100 \\
\hline
\end{tabular}

Table 2.

\begin{tabular}{|c|c|c|c|c|c|c|}
\hline \multirow{2}{*}{ University } & \multirow[b]{2}{*}{77} & \multirow[b]{2}{*}{ '78 } & \multicolumn{2}{|c|}{ Graduates } & \multirow[b]{2}{*}{ '81 } & \multirow[b]{2}{*}{ '82 } \\
\hline & & & & '80 & & \\
\hline British Columbia & & 80 & 80 & 80 & 80 & 80 \\
\hline Alberta & & & 70 & 70 & & 70 \\
\hline Lakehead & & 55 & 55 & 55 & 55 & 55 \\
\hline Toronto & & 65 & 85 & 72 & 75 & 75 \\
\hline Laval & & 130 & 145 & 175 & 160 Est. & . 160 \\
\hline $\begin{array}{l}\text { New Brunswick } \\
\text { BScF }\end{array}$ & & 55 & 60 & 60 & 60 & 55 \\
\hline New Brunswick & & & & & & \\
\hline BScFE & & 13 & 15 & 25 & 25 & 25 \\
\hline Total & & 470 & 510 & 537 & 525 & 520 \\
\hline $\begin{array}{l}\text { Remaining in } \\
\text { Canadian Forestry }\end{array}$ & & 423 & 459 & 483 & 472 & 468 \\
\hline $\begin{array}{l}\text { Accumulated Total } \\
\text { practicing }\end{array}$ & & & & & & \\
\hline $\begin{array}{l}\text { Foresters } \\
\% \text { increase }\end{array}$ & $36 \mathrm{CO}$ & $\begin{array}{r}4023 \\
12\end{array}$ & $\begin{array}{r}4482 \\
11\end{array}$ & $\begin{array}{r}4965 \\
11\end{array}$ & $\begin{array}{r}5437 \\
10\end{array}$ & $\begin{array}{r}6905 \\
9\end{array}$ \\
\hline
\end{tabular}

\section{Conclusions}

There are two conclusions that I would draw from the above:

A. There is a potential of almost doubling the Active membership in the CIF (Table 1).

B. There are going to be a lot of Foresters looking for jobs in the next five years.

\section{Acknowledgements}

The six Forestry schools, the four provincial associations and provincial representatives across the country helped provide the figures for this article. I would like to thank them.

Any facts, figures or comments that would tend to adjust the above estimates, bringing them closer to what you think is more accurate will be appreciated.

A. G. Racey

Table 3

First Year Graduates

\begin{tabular}{|c|c|c|c|c|c|}
\hline \multirow[b]{3}{*}{ University } & 1 & 2 & 3 & 4 & 5 \\
\hline & \multicolumn{2}{|c|}{$\begin{array}{c}\text { Taking } \\
\text { Post-Graduate } \\
\text { Courses }\end{array}$} & \multirow{2}{*}{$\begin{array}{l}\text { Staying in } \\
\text { Forestry but } \\
\text { leaving the } \\
\text { province }\end{array}$} & \multirow{2}{*}{$\begin{array}{l}\% \\
\text { Staying in } \\
\text { Forestry but } \\
\text { leaving the } \\
\text { country }\end{array}$} & \multirow{2}{*}{$\begin{array}{c}\% \\
\begin{array}{c}\text { Leaving } \\
\text { Forestry }\end{array}\end{array}$} \\
\hline & $\begin{array}{c}\% \\
\text { Forestry }\end{array}$ & $\begin{array}{c}\% \\
\text { Non-Forestry }\end{array}$ & & & \\
\hline 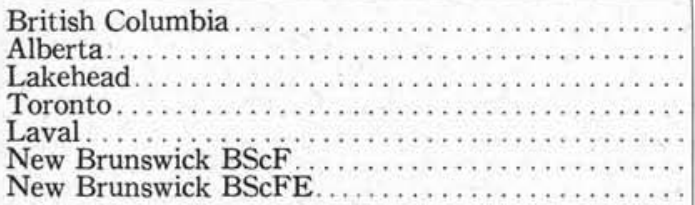 & $\begin{array}{r}5 \\
5 \\
10 \\
8 \\
2 \\
0\end{array}$ & 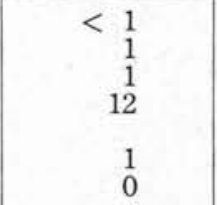 & $\begin{array}{r}5 \\
50 \\
20 \\
15\end{array}$ & $\begin{array}{l}2 \\
1 \\
5 \\
5\end{array}$ & $\begin{array}{r}3 \\
10 \\
5 \\
15\end{array}$ \\
\hline
\end{tabular}

